\title{
Biological vulnerability in the Elqui Valley (Coquimbo Region, Chile) to economically important arthropods
}

\author{
Jaime Pizarro-Araya ${ }^{1}$, Jorge Cepeda-Pizarroํㅜ Juan E. Barriga ${ }^{2}$, and Andrés \\ Bodini $^{3}$
}

${ }^{1}$ Laboratorio de Entomología Ecológica, Departamento de Biología, Facultad de Ciencias, Universidad de La Serena, Casilla 599, La Serena, Chile. ${ }^{2}$ Departamento de Ciencias Agrarias, Facultad de Ciencias Agrarias y Forestales, Universidad Católica del Maule, Casilla 139, Curicó, Chile, and 'Proyecto Canadá, Dirección de Extensión, Universidad de La Serena, Prat 446, La Serena, Chile.

\begin{abstract}
J. Pizarro-Araya, J. Cepeda-Pizarro, J.E. Barriga, and A. Bodini. 2009. Biological vulnerability in the Elqui Valley (Coquimbo Region, Chile) to economically important arthropods. Cien. Inv. Agr. 36(2):215-228. Current climate conditions in north-central Chile $\left(25^{\circ} 57^{\prime}-32^{\circ} 13^{\prime} \mathrm{S}, 71^{\circ} 43^{\prime}-68^{\circ} 16^{\prime} \mathrm{W}\right)$ are characterized by increasing temperatures and decreasing rainfall. Global warming is expected to alter the hydrology and ecoclimatic characteristics of north-central basins with multiple effects, including changes in plant and arthropod phenology and biodiversity. Among these basins, the Elqui Valley $\left(29^{\circ} 50^{\prime} \mathrm{S}, 70^{\circ} 52^{\prime} \mathrm{W}\right)$ stands out for its large population and the economic importance of tourism and agriculture. The taxonomic composition of agriculturally and medically important arthropods was studied in three locations in the Elqui Valley by manual capture of specimens and interviews with farmers, agricultural workers, and local leaders. Out of a total of 145 species of insects and 36 species of arachnids, 36 insects and 1 arachnid are considered pests and are known to attack one or more host plants. Four orders dominated the insect suryes: Coleoptera (31.3\% of the total captured), Orthoptera (13.9\%), Hymenoptera (9.3\%), and Lepidoptera (13.4\%). Some agriculturally important insects include Macrosiphum, Rhopalosiphum, Myzus (Aphididae), Coccus, Parthenolecanium, Saissetia (Coccidae) and Pseudococcus (Pseudococcidae). Some medically important species are those in the zoonotic genera Loxosceles, Latrodectus, Triatoma, and Mepraia. The study of agriculturally and medically important arthropods will improve the design of better of management plans to minimize the vulnerability of ecosystems to climate change.
\end{abstract}

Key words: Arthropods, climate change, agricultural cropland, rangeland, Elqui Valley, arid zones.

\section{Introduction}

Impacts on the planet's climate associated with changes in the composition of the atmosphere

Received 20 August 2008. Accepted 07 November 2008.

Corresponding author: japizarro@userena.cl were hypothesized at the end of the 19th century, but it was not until a century later in the late 1980 s that the international community became convinced of this (IPCC, 2001). The IPCC (2005) states that throughout the 20th century and especially during the 1990s, the average temperature of the Earth's surface increased by 0.2 to $0.6^{\circ} \mathrm{C}$. There is a consensus among climate change researchers that the temperature 
of the Planet will increase by several degrees in the next 50 to 100 years that the precipitation will decrease (Schneider, 1993; IPCC, 2005).

Average temperatures are expected to increase 2 to $4^{\circ} \mathrm{C}$ over much of continental Chile (Mooney et al., 2001; González and Velasco, 2008). Several studies (Arroyo et al., 1993; Villagrán and Armesto, 1993) warn of possible aridization in the Mediterranean climate region $\left(30-38^{\circ} \mathrm{S}\right)$ and a decrease in precipitation. Ecosystems vulnerable to climate change include basins dependent on snowfall, such as the Elqui river basin (29 35'-30 20'S, with an area of $\left.9,437 \mathrm{~km}^{2}\right)(\mathrm{Za}-$ vala and Trigos, 2009).

Changes in average temperature could change the hydrology and ecoclimatic features of the basin (CONICYT, 1989; Andrade and Peña, 1993; Aceituno et al., 1993) and could have many effects on the biota of the ecosystem (Arroyo et al., 1993; Contreras, 1993; Mooney et al., 2001). According to Schotterer et al. (2003), snow basins would be seriously affected by climate-induced changes. The climatic, physiographic and ecological features that characterize the Elqui river basin make it a highly vulnerable natural system (Khodayar et al., 2008; Fiebig-Wittmaack et al., 2009; Pérez et al., 2009). Additionally, climate change may alter the ecological balance of arthropods, entomopathogenic vectors and vegetation in this system (Parson et al., 2003; Andrew and Hughes, 2005; Kleespies et al., 2008).

It is well known that meteorological factors play an important role in the population dynamics of animals in Chilean arid and semiarid environments (Jaksic and Lazo, 1999; Jaksic, 2001; Lima and Jaksic, 1999; Jaksic and Lima, 2003; CepedaPizarro et al., 2005a,b, 2006, 2007). In the Elqui Valley, outbreaks associated with weather patterns have been observed in small rodent and some arthropod populations (Péfaur et al., 1979; Fuentes and Campusano, 1985; Pérez et al., 2009). With the exception of valley bottoms, which are supplied with water, the rangeland the basin has very pronounced desert-like characteristics. The geochemical compositions of soils plays a fundamental role in determining its properties (Oyarzún et al., 2006). Due to this, agriculture in the Elqui $\mathrm{V}$ (EV hereafter) takes place mainly in the bottom valleys and in the neighbouring coastal plains.
The ecoclimatic differences at different altitudes directly determines where certain crops the soil and determines where certain crops are cultivated (CONAF, 2004). At lower altitudes, which are influenced by high coastal clouds, fresh vegetables predominate, such as lettuce (Lactuca sativa L.), chili pepper (Capsicum annuum L.), cumin (Cuminum cyminum L.) and onion (Allium cepa L.), as do papaya (Carica candamarcensis Hook.f.), cherimoya (Annona cherimola Mill.), and lucuma (Pouteria lucuma (Ruiz and Pav.) Kuntze). At middle altitudes, which tend to be highly isolated, the main crops are tomato (Lycopersicon esculentum Mill.) and chili (Capsicum spp.), while the production of grapevine (Vitis vinifera L.) predominates at high altitudes (Novoa and Villaseca, 1989). These crops interact with many different insect species. In Chile, 385 insects and 24 mite species are considered to be potentially important agricultural pests (Artigas, 1994; Klein and Waterhouse, 2000; Rojas, 2005).

The objectives of this study were: (1) to document, at the genus or species level, the taxonomic composition of arachnids and insects in range and cropland in the $\mathrm{EV}$, (2) to determine the presence of agriculturally and medically important species in the valley and (3) to establish a database of biodiversity of arthropods related to climatic variability in the Elqui Valley.

\section{Materials and methods}

\section{Study sites}

The research was carried out in the EV (Elqui Province, Coquimbo Region, Chile) (Figure 1). The average annual rainfall in the study area is approximately $104 \mathrm{~mm}$, being June the wettest month with $25.9 \mathrm{~mm}$. Estimated evaporation is $1,220 \mathrm{~mm}$ a year, with a maximum of $172 \mathrm{~mm}$ in January and a minimum of $47 \mathrm{~mm}$ in June. The dry season lasts nine months. The average monthly temperature stays above $10^{\circ} \mathrm{C}$ throughout the year (Novoa and Villaseca, 1989).

To determine the presence of agriculturally and medically important arthropods, surveys and interviews were carried out in three altitudinal sectors: Marquesa $\left(29^{\circ} 56^{\prime} 29.7^{\prime \prime} \mathrm{S}\right.$, 
$70^{\circ} 57^{\prime} 28.5^{\prime \prime} \mathrm{W} ; 373 \mathrm{~m}$ elevation, average annual precipitation $71.4 \mathrm{~mm})$, Diaguitas $\left(30^{\circ} 00^{\prime} 30.4^{\prime \prime} \mathrm{S}\right.$, $70^{\circ} 37^{\prime} 33.7^{\prime \prime} \mathrm{W}$; $855 \mathrm{~m}$, average annual precipitation $98.5 \mathrm{~mm}$ ), and Pisco Elqui (30 $30^{\circ} 7^{\prime} 27.5^{\prime \prime} \mathrm{S}$, $70^{\circ} 29^{\prime} 41.2^{\prime \prime} \mathrm{W} ; 1272 \mathrm{~m}$, average annual precipitation $115.3 \mathrm{~mm}$ ) (Figure 1). (i) Insecta nomenclature, Artigas (1994), Ripa and Rodríguez (2000), Estay and Bruna (2002), Rojas (2005); (ii) Araneae, Zapfe (1961), Kaston (1978), Platnick (1983, 2008), Roth (1993), Goloboff(1995), Ramírez (1999); (iii) Solifugae, Muma (1971), Maury (1984, 1987), El-Hennawy

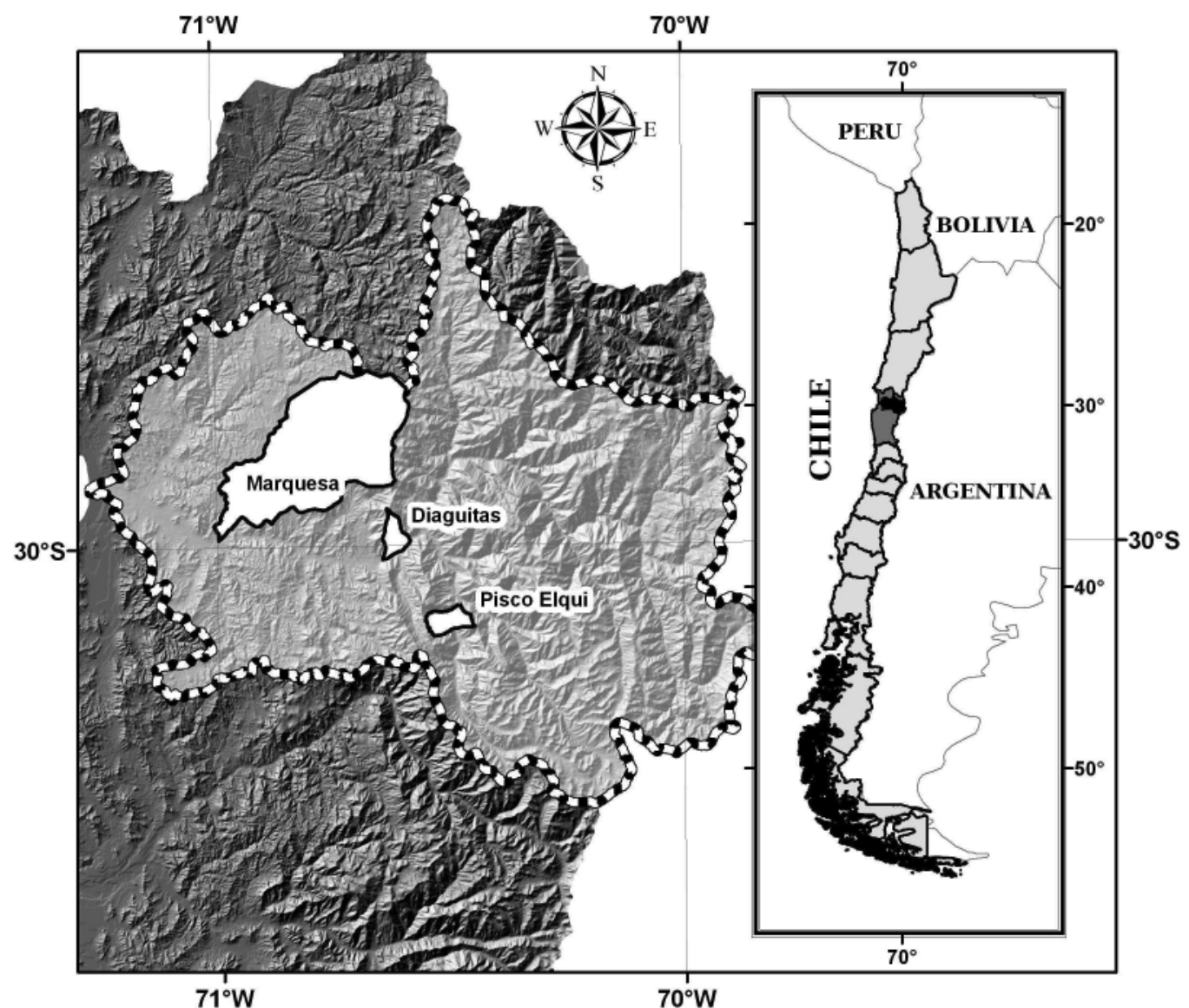

Figure 1. Location of the three study areas in the Elqui Valley (Coquimbo Region, Chile): Marquesa (29 $56^{\prime} 29.7^{\prime \prime} \mathrm{S}$,

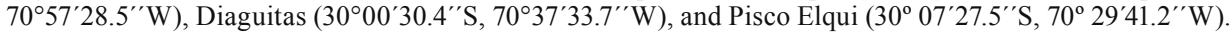

Capture methods and information collection

The surveys were conducted in January 20062008 with insect capturing devices, including nets, umbrellas, and fans. Additionally, farmers, stakeholders, community leaders, agricultural and orchard workers were interviewed. Information was checked and completed with literature reviews. When possible the captured specimens to the species or morphospecies level through the following taxonomic keys:
(1990); (iv) Scorpiones, Lourenço (1995), Mattoni and Acosta (2006), Agusto et al. (2006); (v) Acari, Krantz (1978). Comparisons were made with the following entomological collections: JEBC (Juan Enrique Barriga Private Collection, Curicó, Chile), LEULS (Laboratorio de Entomología Ecológica, Universidad de La Serena, La Serena, Chile), MNNC (Museo Nacional de Historia Natural, Santiago, Chile), UCCC (Universidad de Concepción, Concepción, Chile). The captured specimens were deposited in the JEBC, LEULS and MNNC collections. 


\section{Results and discussion}

Taxonomic composition of Arthropoda in range and cropland in the Elqui Valley

Insects comprised $89.3 \%$ of the specimens collected. The remaining percentage was made up of Araneae, Solifugae, Scorpiones and Acari arachnids (i.e., Ixodidae, Tetranychidae). Four orders dominated the Insecta: Coleoptera $(31.3 \%)$, Orthoptera (13.9\%), Hymenoptera (9.3\%), and Lepidoptera (13.4\%). The main families were Tenebrionidae, Buprestidae, and Coccinelidae (Coleoptera); Acrididae, Gryllidae and Tristiridae (Orthoptera); Vespidae, Apidae and Sphecidae (Hymenoptera); Nymphalidae, Pieridae, Lycaenidae and Hesperiidae (Lepidoptera). Less common taxa were Thysanura, Phthiraptera, Siphonaptera and unidentified flying species of Neuroptera and Odonata. Araneae, with 17 families, were numerically predominant among arachnids, along with Solifugae $(1.6 \%$ of the total captured) and Scorpiones $(0.8 \%$ of the total captured) (Table 1).

Table 1. Presence and abundance of arthropods in range and croplands in the three study area in the Elqui Valley (Coquimbo Region, Chile).

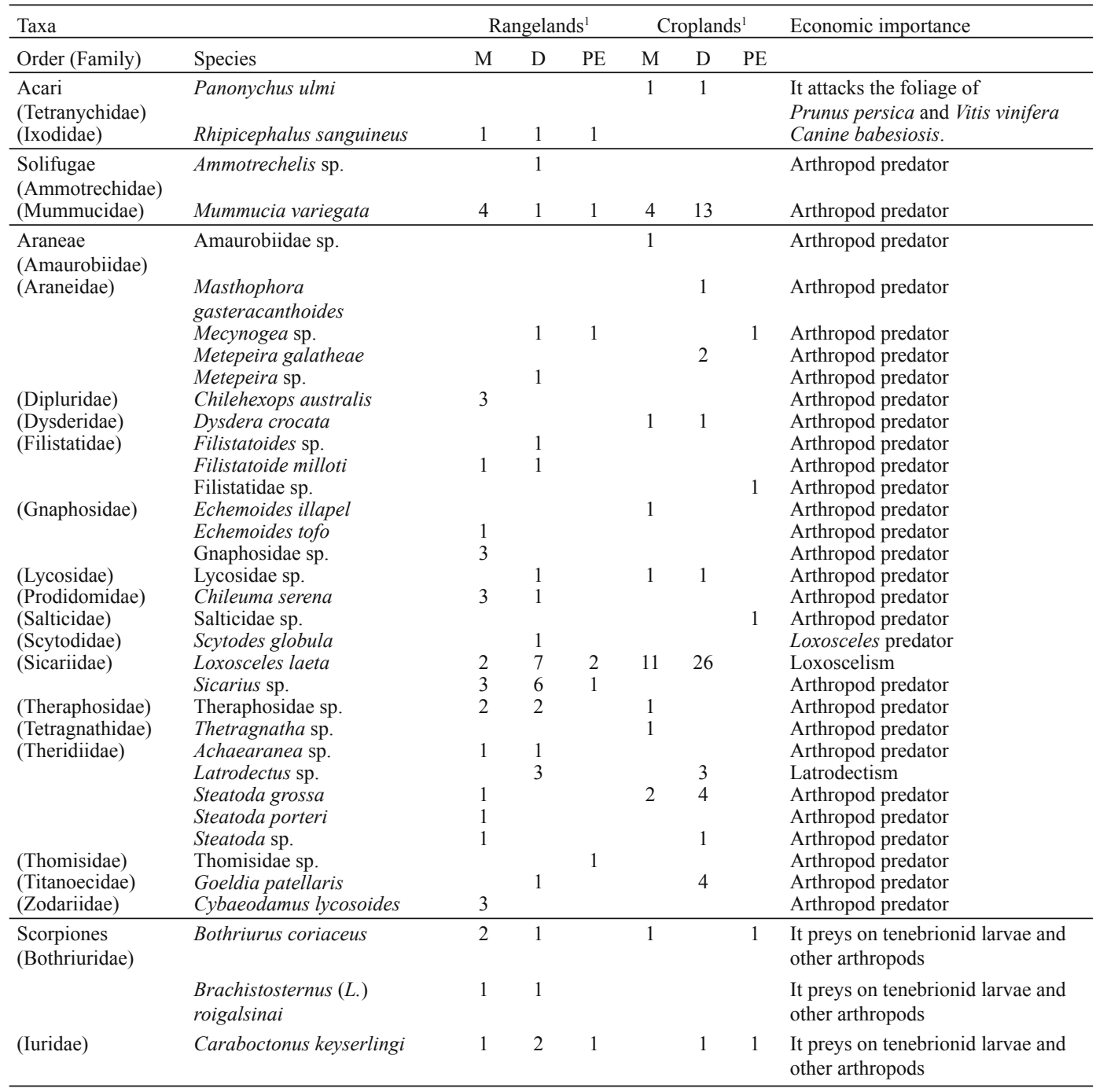




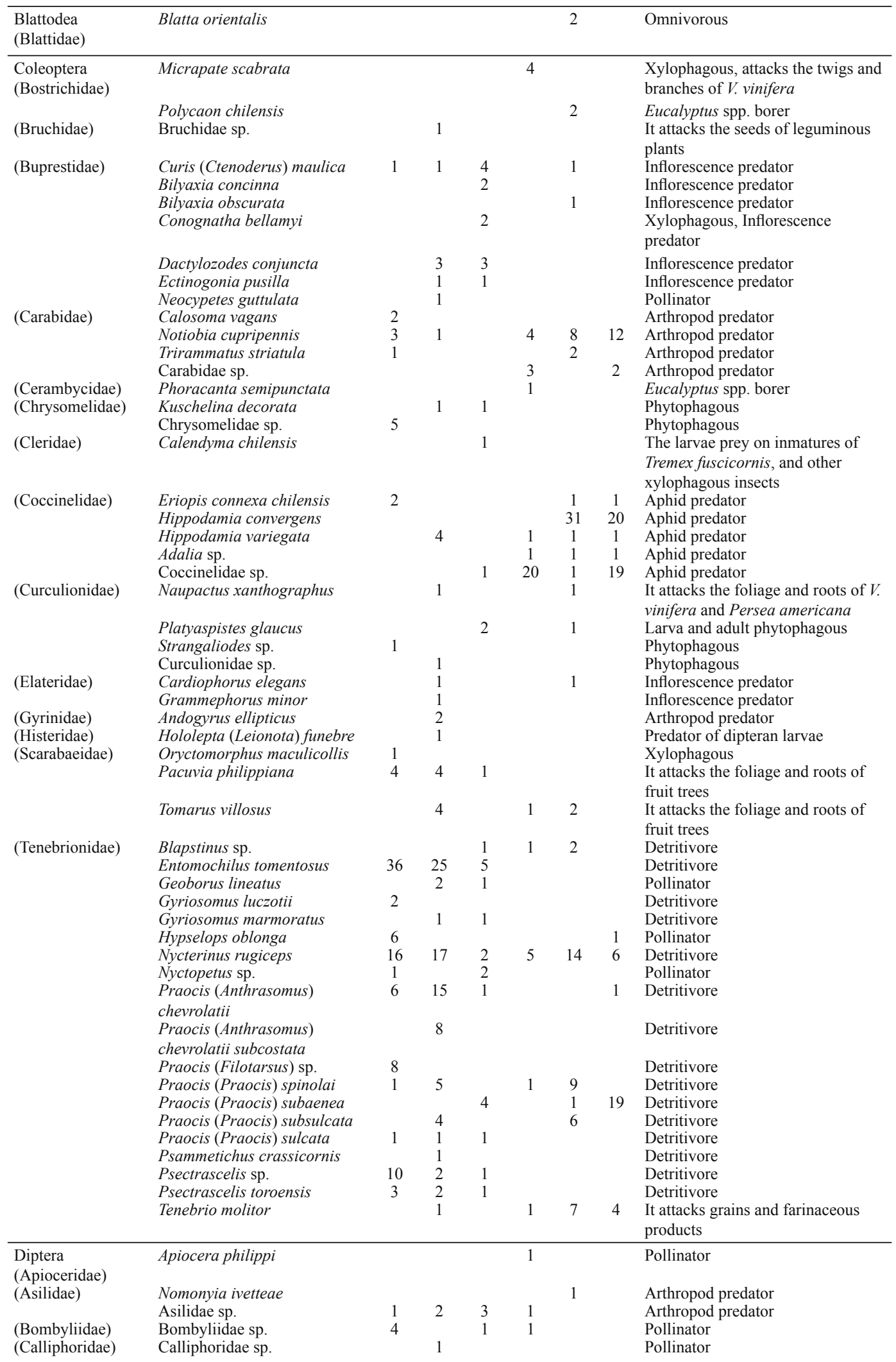




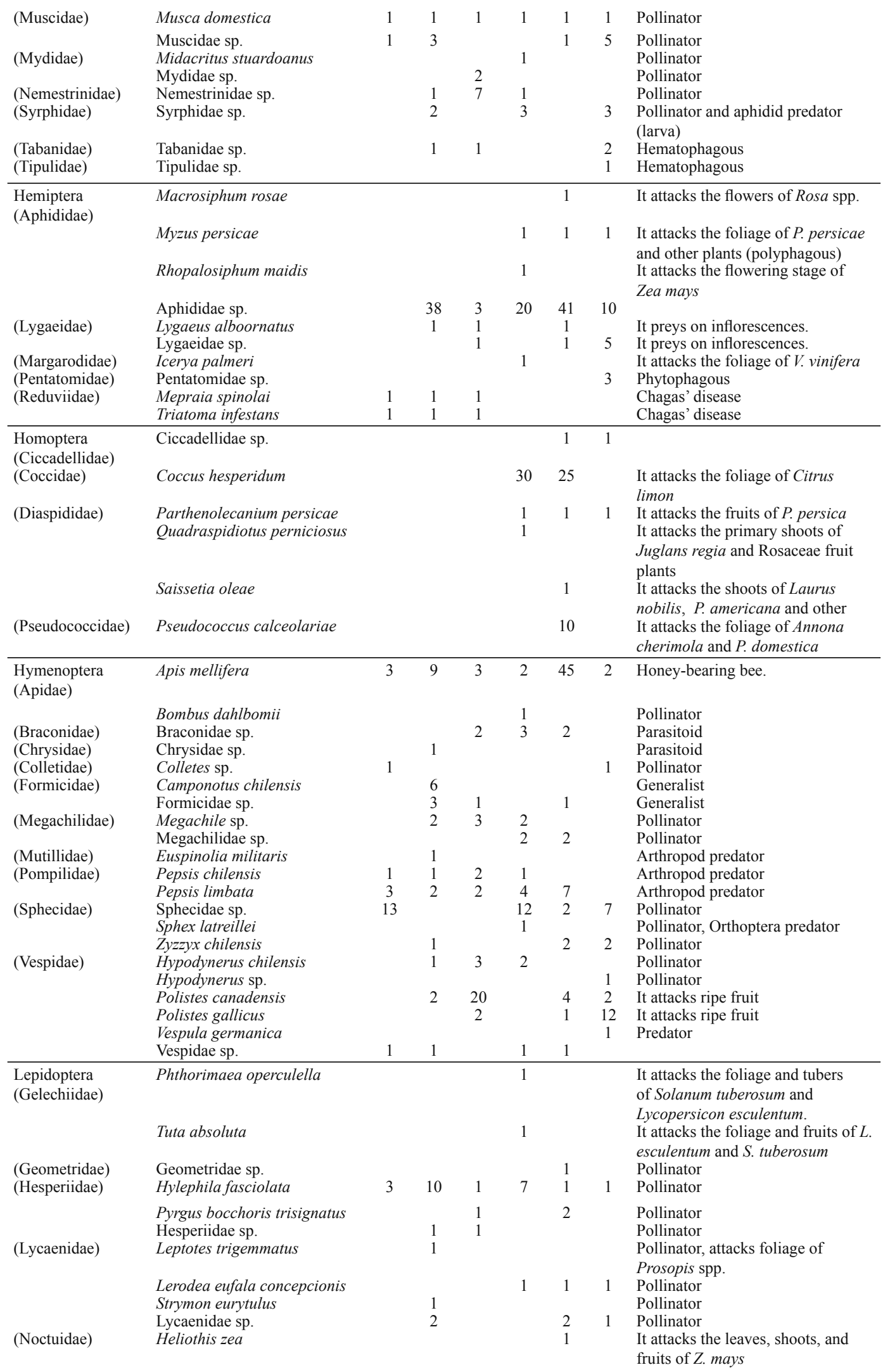




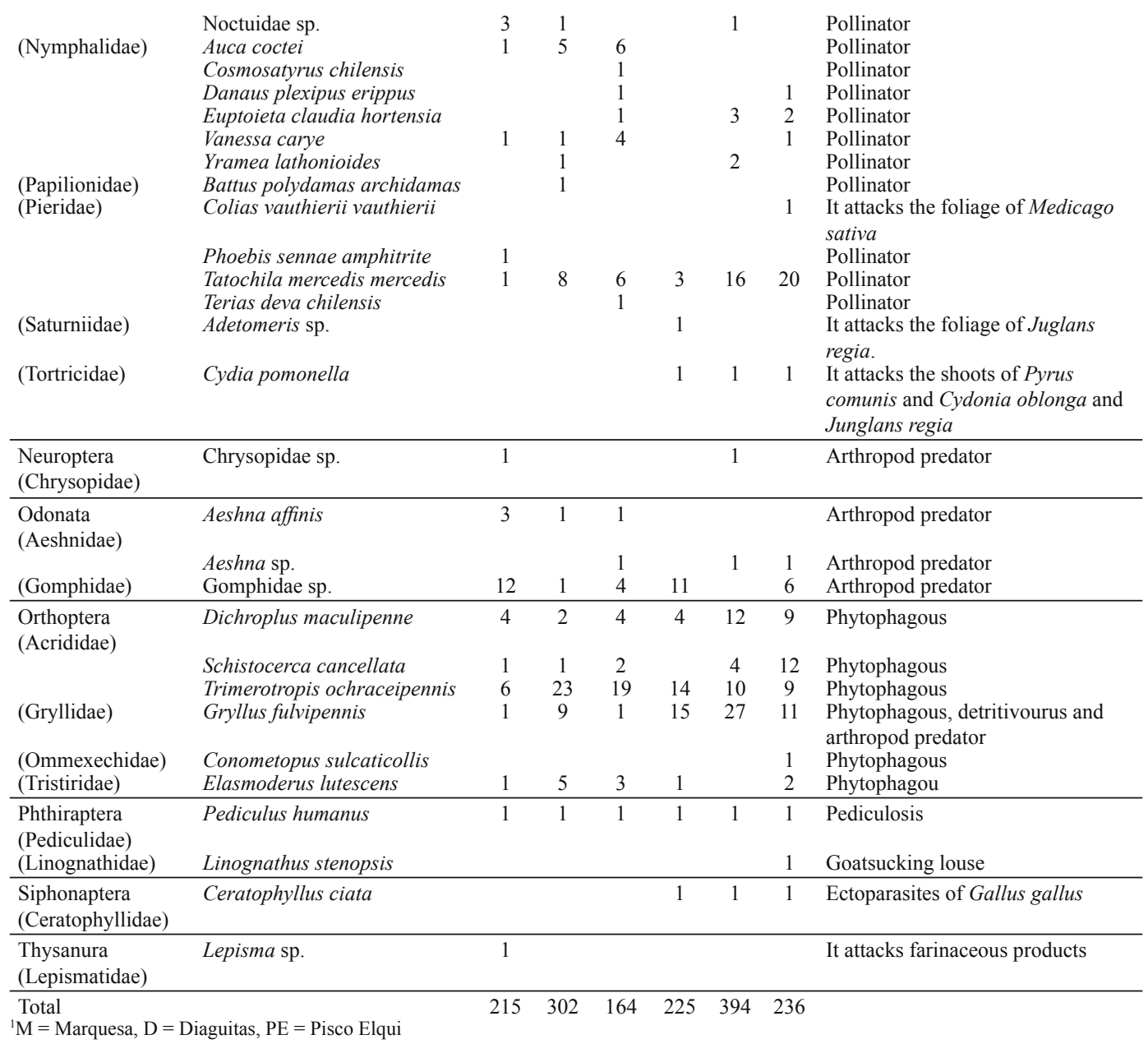

Species diversity increased with altitude of the studied sectors. The Marquesa (373 m) and Diaguitas $(855 \mathrm{~m})$ areas were the most diverse, with 105 and 130 species, respectively. In Pisco Elqui, the study area at the highest altitude (1,272 m), 98 species were collected. Similarly, the rangeland around Marquesa and Diaguitas were more diverse than Pisco Elqui.

Agriculturally important arthropods in the Elqui Valley

Nineteen percent of the collected species are potential agricultural pests. Among Insecta, Hemiptera, with Aphididae (Macrosiphum, Rhopalosiphum, Myzus) and Margarodidae (Icerya), was the main taxon affecting vegetables and fruit trees in the areas studied, followed by Homoptera, with Coccidae (Coccus, Parthenolecanium, Saissetia) and Pseudococcidae (Pseudococcus), which attack the foliage of fruit trees. Relevant Lepidoptera were Phthorimaea and Tuta (Gelechiidae), whose larvae destroy leaves, and Cydia (Tortricidae), whose immature stages bore holes in fruits or tree branches. Although not captured in the entomological survey, the presence of the European grapevine moth, Lobesia botrana (Denis and Schiffermuller) (Lepidoptera: Tortricidae), has been detected in the Vicuña sector $\left(30^{\circ} 02^{\prime} 00^{\prime \prime} \mathrm{S}\right.$, $\left.70^{\circ} 43^{\prime} 00^{\prime \prime} \mathrm{W} ; 610 \mathrm{~m}\right)$ (SAG, 2008). This moth is a major grapevine pest, but despite the abundance of vineyards, it is a generalist and uses either grapes or alternative species (Thiéry and Moreau, 2005; ASOEX, 2008). The only economically important arachnida found was Panonychus ulmi (Koch) (Acari: Tetranychi- 
dae), which causes early damage to the foliage of Prunus persica L. and $V$. vinifera.

\section{Medically important arthropods in the Elqui Valley}

Loxoscelism, which is caused by a bite from species of the genus Loxosceles (Araneae: Sicariidae) (Hogan et al., 2004; Vetter, 2008) is a prevalent and important condition in the area due to the frequent presence of this nocturnal spider in houses and to the high morbidity and mortality caused by its poison, which can cause skin necrosis, hemolysis, vasculitis and coagulopathy (Schenone, 2003; Zambrano et al., 2005). Another important zoonosis in the area is latrodectism, which is caused by the fanerotoxic spiders of the genus Latrodectus (Araneae: Theridiidae) (Canals et al., 2004). The poison of this spiders is composed of several neurotoxins causing complex clinical symptoms (tachycardia, hypertension and priapism) and even death (Vetter and Isbister, 2008). These zoonoses are prevalent throughout north-central Chile, particularly in transversal valleys in the Coquimbo region (Delgado, 2000; Canals et al., 2004).

Another medically important arachnid found in the study area is the tick Rhipicephalus sanguineus (Latr.) (Acari: Ixodidae). This species, which was found in all three areas, causes canine babesiosis. These ectoparasites were collected from dogs (Canis familiaris L.) in rangeland in the Elqui Valley (Table 1). The species is univoltine, with periods of activity in spring-summer; the diapause occurs generally in the adult stage and secondarily in nymphs. Bourdeau (1993) documented that the interior of houses is not a reservoir of $R$. sanguineus but that rangeland is more important in the maintenance of canine babesiosis vectors.

Among Insecta, Triatoma infestans (Klug) and Mepraia spinolai (Por.) (Hemiptera: Reduviidae) are present in the rangeland areas in the three study sectors, are vectors for Chagas disease and cause parasitosis in inhabitants of the Elqui Valley, especially in the "Norte Chico" part of the region (Arribada et al., 1990). Frías et al. (1998) documented the presence of male M. spinolai in the towns of Vicuña and Paihua- no. However, the presence of rodent-borne disease must be also considered, and species of the genera Abrothrix, Octodon, Oligoryzomys and Phyllotis predominate (C. Zuleta, personal communication). Another insect of medical importance found in the valley was Pediculus humanus (Phthiraptera: Pediculidae), a human ectoparasite that causes pediculosis (Artigas, 1994).

Presence of arthropod pests in rangeland areas in the Elqui Valley

The presence of Conometopus sulcaticollis (B1.), Schistocerca cancellata (Audinet-Serville), and Trimerotropis sp. populations (Orthoptera: Acrididae) in rangeland in the study areas represents a possible outbreak of these orthopterans. Cepeda-Pizarro et al. (2003) has documented that in some rangeland in the Chilean transitional desert region (25-32 S), some Orthoptera species (e.g., Elasmoderus: Tristiridae) have the potential for rapid outbreaks, with population densities between 0.49 and $0.58 \mathrm{ind} / \mathrm{m}^{2}$ (Cepeda-Pizarro et al., 2006, 2007). Cepeda-Pizarro et al. (2007) analyzed temperatures and precipitation during outbreaks of E. wagenknecht, and found that higher summer temperatures, lower rainfall and deviations from historical rainfall patterns may induce E. wagenknechti outbreaks. This evidence may be biased because of strong chemical insecticides applied early in the season. This result suggests that insect control techniques must be promoted among the farmers in this region, and environmentally innocuous insecticides would be preferable, such as insect growth regulators, biological insecticides and "barrier" fumigation, rather than total coverage treatments.

It is estimated that almost one-third of the world's agricultural harvest is lost yearly due to parasites, and arthropods (specifically insects) result in the greatest amount of crop damage worldwide (Retana, 2000). World agricultural output dropped by $15 \%$ in the last decade due to entomological infestation (Mueller et al., 2005; Kleespies et al., 2008). The findings in the current study provide a baseline to manage possible arthropod outbreaks in the Elqui Valley. Rainfall 
and temperature changes can result in outbreaks of some arthropods (Fuentes and Campusano, 1985). Above average temperatures and below average precipitation may trigger outbreaks of rangeland insect species (e.g., grasshoppers) has been documented for ecosystems at other latitudes (Carey, 2001). Various hypotheses have been formulated to explain the occurrence of arthropods outbreaks, including alterations in flora and the availability of resources (Doran et al., 2003), soil modification (Skinner and Child, 2000) and weather patterns (Volney and Fleming, 2000). Weather patterns appear to be of particular importance to outbreaks of herbivorous insects (Capinera and Horton, 1989; Fielding and Brusven, 1990; Lockwood et al., 2000; Bock et al., 2006). The importance of climate varies with latitude (Capinera and Horton, 1989; Joern and Gaines, 1990). For example, at intermediate latitudes in North America, precipitation is a more important factor than temperature; species are apparently more limited by the availability of food than by developmental duration (Capinera and Horton, 1989; Lockwood and Lockwood, 1991). At high latitudes, the abundance of insects is negatively related to precipitation, which may be due to pathogenic action or longer developmental times (Gage and Mukerji, 1977; Skinner and Child, 2000). On the other hand, warm, dry conditions favor increased insects populations at low latitudes, in mountainous areas, in temperate and in areas with seasonal rains
(Joern and Gaines, 1990). Because of the variability in temperature and precipitation, detailed study of agriculturally and medically important arthropods will allow the creation of better management plans to minimize the vulnerability of ecosystems to climate change.

\section{Acknowledgments}

We thank Carlos Zuleta (Laboratorio de Ecología de Vertebrados, Universidad de La Serena) for providing rodent data for the Elqui Valley, Alex Cea (Laboratorio de Ecología Vegetal, Universidad de La Serena) for providing botanical assistance, José Mondaca (SAG, Santiago, Chile) for providing data about Coleoptera and Pía Espinoza Guerrero (Carrera Traductor Ingles-Español, Departamento de Artes y Letras, Universidad de La Serena) for English proofreading. This research was conducted as part of the following projects: Institutional adaptations to climate change: comparative study of dryland river basins in Canada and Chile (SSHRC-MCRI Project), University of Regina (Canada) - Universidad de La Serena (Chile) and DIULS-PF07101 of the Universidad de La Serena, La Serena (JPA). This work is also part of the program "Ecology and taxonomic diversity of arthropods and vertebrates of the transitional coastal desert of Chile" of the Departamento de Biología, Universidad de La Serena, Chile. 


\title{
Resumen
}

\begin{abstract}
J. Pizarro-Araya, J. Cepeda-Pizarro, J.E. Barriga y A. Bodini. 2009. Vulnerabilidad biológica en el Valle de Elqui (Región de Coquimbo, Chile) en artropodos economicamente importantes. Cien. Inv. Agr. 36(2):215-228. Las condiciones climáticas actuales del norte-centro de Chile se caracterizan por el aumento de la temperatura y la disminución de la precipitación. En este escenario, se espera que el calentamiento global altere el balance hídrico y las características ecoclimáticas de las cuencas, con diversos efectos (ej., alteración de la fenología de plantas y artrópodos; cambios en la riqueza y biodiversidad local) sobre el ecosistema. Entre estas cuencas, se destaca la cuenca del Valle de Elqui (Región de Coquimbo, Chile), que alberga una población humana importante y es un destacado foco económico en términos de actividades agrícolas y turísticas. En este contexto, mediante colectas manuales y entrevistas a agricultores, se estudió la composición taxonómica del ensamble de artrópodos de importancia agrícola y médica en tres localidades del Valle de Elqui. Treinta y seis de 145 especies de insectos y una de 36 especies de arácnidos son consideradas plagas de importancia agrícola que atacan a uno o más hospederos. Cuatro ordenes dominaron el ensamble de Insecta: Coleoptera (31,3\% de total capturado), Orthoptera (13,9\%), Hymenoptera $(9,3 \%)$, Lepidoptera (13,4\%). Entre los insectos de importancia agrícola se destaca la presencia de Macrosiphum, Rhopalosiphum, Myzus (Aphididae); Coccus, Parthenolecanium, Saissetia (Coccidae) y Pseudococcus (Pseudococcidae). Entre las especies de importancia médica se destacan los géneros zoonóticos Loxosceles, Latrodectus, Triatoma y Mepraia. El estudio y conocimiento detallado de estos artrópodos permitirá establecer planes de monitoreo y control que minimicen la vulnerabilidad del sistema frente a las modificaciones ambientales derivados del cambio climático.
\end{abstract}

Palabras clave: Artrópodos, cambio climático, cultivos agrícolas, secano, Valle de Elqui, zonas áridas.

\section{References}

Aceituno, P., H. Fuenzalida, and B. Rosenblüth. 1993. Climate along the extratropical west coast of South America. Pages 61-69. In: H.A. Mooney, E.R. Fuentes, and B.I. Kronberg (eds.). Earth System Response to Global Change. Academic Press, San Diego, USA.

Agusto, P., C.I. Mattoni, J. Pizarro-Araya, J. CepedaPizarro, and F. López-Cortés. 2006. Comunidades de escorpiones (Arachnida: Scorpiones) del desierto costero transicional de Chile. Revista Chilena de Historia Natural 79:407-421.

Andrade, B., and H. Peña. 1993. Chilean geomorphology and hydrology: response to global change. Pages 101-113. In: H.A. Mooney, E.R. Fuentes, and B.I. Kronberg (eds.). Earth System Response to Global Change. Academic Press, San Diego, USA.

Andrew, N.R., and L. Hughes. 2005. Arthropod community structure along a latitudinal gradient: Implications for future impacts of climate change. Austral Ecology 30:281-297.
Arribada, A., W. Apt, X. Aguilera, A. Solari, A. Arribada, and J. Sandoval. 1990. Chagas cardiopathy in the first region of Chile. Clinical, epidemiologic and parasitologic study. Revista Médica de Chile 118:846-854.

Artigas, J.N. 1994. Entomología económica. Insectos de interés agrícola, forestal, médico y veterinario. Volúmenes I \& II, Ediciones Universidad de Concepción. Concepción, Chile. 1126 and 943 pp. (respectively).

Arroyo, M.T.K., J.J. Armesto, F.A. Squeo, and J. Gutiérrez. 1993. Global change: flora and vegetation of Chile. Pages 239-263. In: H.A. Mooney, E.R. Fuentes, and B.I. Kronberg (eds.). Earth System Response to Global Change. Academic Press, San Diego, USA.

ASOEX. 2008. Programa Fitosanitario para el control de Lobesia botrana en uva de mesa. Santiago, Chile. 7 pp.

Bock, C.E., Z.F. Jones, and J.H. Bock. 2006. Grasshopper Abundance in an Arizona Rangeland Undergoing Exurban Development. Rangeland Ecology \& Management 59: 640-647.

Bourdeau, P. 1993. La babésiose canine (Babe- 
sia canis). Recueil de Medecine Veterinaire 169:439-450.

Canals, M., M.E. Casanueva, and M. Aguilera. 2004. ¿Cuáles son las especies de arañas peligrosas en Chile? Revista Médica de Chile 132:773-776.

Capinera, J.L., and D.R. Horton. 1989. Geographic variation in effects of weather on grasshopper infestation. Environmental Entomology 18:8-14.

Carey, J.R. 2001. Insect biodemography. Annual Review of Entomology 46:79-110.

Cepeda-Pizarro, J., J. Pizarro-Araya, and H. Vásquez. 2005a. Composición y abundancia de artrópodos epígeos del Parque Nacional Llanos de Challe: impactos del ENOS de 1997 y efectos del hábitat pedológico. Revista Chilena de Historia Natural 78:635-650.

Cepeda-Pizarro, J., J. Pizarro-Araya, and H. Vásquez. 2005b. Variación en la abundancia de Arthropoda en un transecto latitudinal del desierto costero transicional de Chile, con énfasis en los tenebriónidos epígeos. Revista Chilena de Historia Natural 78:651-663.

Cepeda-Pizarro, J., S. Vega, H. Vásquez, and M. Elgueta. 2003. Morfometría y dimorfismo sexual de Elasmoderus wagenknechti (Liebermann) (Orthoptera: Tristiridae) en dos eventos de irrupción poblacional. Revista Chilena de Historia Natural 76:417-435.

Cepeda-Pizarro, J., S. Vega, M. Elgueta, and J. Pizarro-Araya. 2006. Algunos antecedentes meteorológicos que explican las irrupciones de Elasmoderus wagenknechti (Orthoptera: Tristiridae) en la región del semiárido de Chile. IDESIA (Chile) 24:49-63.

Cepeda-Pizarro, J., S. Vega, H. Vásquez, M. Elgueta, and J. Pizarro-Araya. 2007. Demography of two populations outbreaks of Elasmoderus wagenknechti (Orthoptera: Tristiridae) in the semiarid region of Chile. Neotropical Entomology 36:495-502.

CONAF. 2004. Catastro de Uso de Suelo y Vegetación, Cuarta Región de Coquimbo. Corporación Nacional Forestal. Santiago, Chile. 32 pp.

CONICYT. 1989. El cambio global del clima y sus eventuales efectos en Chile. Comité Nacional de Programa Internacional de la Geosfera-Biosfera (IGBP). Comisión Nacional de Investigación Científica y Tecnológica (CONICYT). Santiago, Chile. 26 pp.

Contreras, L.C. 1993. Effect of global climatic change on terrestrial mammals of Chile. Pages 285-293. In: H.A. Mooney, E.R. Fuentes, and B.I. Kron- berg (eds.). Earth System Response to Global Change. Academic Press, San Diego, USA.

Delgado, A.I. 2000. Morfometría de la vinchuca Mepraia (T.) spinolai (Porter, 1934) (Hemiptera, Triatominae) en el Valle del Limarí, IV Región de Coquimbo, Chile. Tesis de Pedagogía en Biología y Ciencias Naturales. Facultad de Ciencias, Universidad de La Serena, La Serena, Chile. 55 pp.

Doran, N.E., J. Balmer, M. Driessen, R. Bashford, S. Grove, A.M.M. Richardson, J. Griggs, and D. Ziegeler. 2003. Moving with the times: baseline data to gauge future shifts in vegetation and invertebrate altitudinal assemblages due to environmental change. Organisms Diversity \& Evolution 3:127-149.

El-Hennawy, H.K. 1990. Key to solpugid families (Arachnida: Solpugida). Serket 2:20-27.

Estay, P., and A. Bruna. 2002. Insectos, ácaros y enfermedades asociadas al tomate en Chile. Colección Libros Instituto de Investigaciones Agropecuarias, $\mathrm{N}^{\circ} 7$, Santiago, Chile. $111 \mathrm{pp}$.

Fiebig-Wittmaack, M., C. Pérez, and E. Lazo. 2009. Aspectos climáticos del Valle de Elqui. Pages 59-80. In: J. Cepeda-Pizarro (ed.). Los Sistemas Naturales de la Cuenca del Río Elqui (Región de Coquimbo, Chile): Vulnerabilidad y Cambio del Clima. Ediciones Universidad de La Serena, La Serena, Chile.

Fielding, D.J., and M.A. Brunsven. 1990. Historical analysis of grasshopper (Orthoptera: Acrididae) population responses to climate in southern Idaho. Environmental Entomology 19:1786-1791.

Frías, D.A., A.A. Henry, and C.R. González. 1998. Mepraia gajardoi: a new species of Triatominae (Hemiptera: Reduviidae) from Chile and its comparison with Mepraia spinolai. Revista Chilena de Historia Natural 71:177-188.

Fuentes, E.R., and C. Campusano. 1985. Pest outbreaks and rainfall in the semiarid region of Chile. Journal of Arid Environments 8:67-72.

Gage, S.H., and M.K. Mukerji. 1977. A perspective of grasshopper population distribution in Saskatchewan and the interrelationship with weather. Environmental Entomology 6:469-479.

Goloboff, P.A. 1995. A revision of the South American spiders of the family Nemesiidae (Araneae, Mygalomorphae). Part I: species from Peru, Chile, Argentina, and Uruguay. Bulletin of the American Museum of Natural History 224:1-189.

González, J., and R. Velasco. 2008. Evaluation of the impact of climatic change on the economic value 
of land in agricultural systems in Chile. Chilean Journal of Agricultural Research 68:56-68.

Hogan, C.J., K.C. Barbaro, and K. Winkel. 2004. Loxoscelism: Old obstacles, new directions. Annals of Emergency Medicine 44:608-624.

IPCC. 2001. Cambio climático 2001: Informe de síntesis. Grupo Intergubernamental de Expertos sobre el Cambio Climático. WMO-UNEP. Geneva, Italy. $184 \mathrm{pp}$.

IPCC. 2005. Workshop on New Emission Scenarios. Laxenburg, Austria. $71 \mathrm{pp}$.

Jaksic, F.M. 2001. Ecological effects of El Niño in terrestrial ecosystems of western South America. Ecography 24:241-250.

Jaksic, F.M., and I. Lazo. 1999. Response of a bird assemblage in semiarid Chile to the 1997-1998 El Niño. Wilson Bulletin 111:527-535.

Jaksic, F.M., and M. Lima. 2003. Myths and facts on ratadas: Bamboo blooms, rainfall peaks and rodent outbreaks in South America. Austral Ecology 28:237-251.

Joern, A., and S.B. Gaines. 1990. Populations dynamics and regulation in grasshoppers. Pages 415-482. In: R.F. Chapman, and A. Joern (eds.). Biology of Grasshoppers. John Wiley and Sons. New York, USA.

Kaston, B.J. 1978. How to Know the Spiders. The Pictured Key Nature Series, Wm. C. Brown Co. Publishers, Dubuque, Iowa, USA. 272 pp.

Khodayar, S., N. Kalthoff, M. Fiebig-Wittmaack, and M. Kohler. 2008. Evolution of the atmospheric boundary-layer structure of an arid Andes valley. Meteorology and Atmospheric Physics 99:181198.

Kleespies, R.G., A.M. Huger, and G. Zimmermann. 2008. Diseases of insects and other arthropods: results of diagnostic research over 55 years. Biocontrol Science and Technology 18:439-484.

Klein, C., and D.F. Waterhouse. 2000. Distribution and importance of arthropods associated with agriculture and forestry in Chile. (Distribución e importancia de los artrópodos asociados a la agricultura y silvicultura en Chile). Aciar Monograph No. 68. Canberra, Australia 231 pp.

Krantz, G.W. 1978. A manual of Acarology. Corvallis. Oregon State University, Oregon, USA. 509 pp.

Lima, M., and F.M. Jaksic. 1999. Population dynamics of three Neotropical small mammals: time series models and the role of delayed densitydependence in population irruptions. Australian Journal of Ecology 24:24-35.
Lockwood, J.A., and D.R. Lockwood. 1991. Rangeland grasshopper (Orthoptera: Acrididae) population dynamics: insights from catastrophe theory. Environmental Entomology 20:970-980.

Lockwood, J.A., A.V. Latchininsky, and M.G. Sergeev (eds.). 2000. Grasshoppers and Grassland Health: Managing Grasshopper Outbreaks Without Risking Environmental Disaster. Kluwer Academic Publishers. Boston, MA, USA. 221 pp.

Lourenço, W. 1995. Considerations sur la morphologie, ecologie et biogeographie de Caraboctonus keyserlingi Pocock (Scorpionida, Iuridae). Boletín de la Sociedad de Biología de Concepción (Chile) 66:63-69.

Mattoni, C.I., and L.E. Acosta. 2006. Systematics and distribution of three Bothriurus species (Scorpiones, Bothriuridae) from central and northern Chile. Studies on Neotropical Fauna and Environment 41:235-250.

Maury, E.A. 1984. Las familias de solífugos americanos y su distribución geográfica (Arachnida, Solifugae). Physis sección C (Argentina) 42:73-80.

Maury, E.A. 1987. Consideraciones sobre algunos Solifugos de Chile (Solifugae: Ammotrechidae: Daesiidae). Revista de la Sociedad Entomológica Argentina 44:419-432.

Mooney, H.A., M.T.K. Arroyo, W.J. Bond, J. Canadell, R.J. Hobbs, S. Lavorel, and R.P. Neilson. 2001. Mediterranean-climate ecosystem. Ecological Studies 152. Pages 157-198. In: F.S. Chapin, O. Sala, and E. Huber-Sammvald. (eds.). Global Diversity in a Changing Environment: Scenarios for the 21st Century. Springer-Verlag, New York, USA.

Mueller, U.G., N.M. Gerardo, D.K. Aanen, D.L. Six, and T.R. Schultz. 2005. The evolution of agriculture in insects. Annual Review of Ecology Evolution and Systematics 36:563-595.

Muma, M.H. 1971. The solpugids (Arachnida: Solpugida) of Chile with descriptions of a new family, new genera, and new species. American Museum Novitates 2476:1-23.

Novoa, R., and S. Villaseca. 1989. Mapa Agroclimático de Chile. Ediciones Instituto de Investigaciones Agropecuarias, INIA, Ministerio de Agricultura, Santiago, Chile. 221 pp.

Oyarzún, J., H. Maturana, A. Paulo, and A. Pasieczna. 2003. Heavy metals in stream sediments from the Coquimbo Region (Chile): effects of sustained mining and natural processes in a semiarid Andean basin. Mine Water and the Environment 22:155-161. 
Parson, E.A., R.W. Corell, E.J. Barron, V. Burkett, A. Janetos, L. Joyce, T.R. Karl, M.C. MacCracken, J. Melillo, M.G. Morgan, D.S. Schimel, and T. Wilbanks. 2003. Understanding climatic impacts, vulnerabilities, and adaptation in the United States: Building a capacity for assessment. Climatic Change 57:9-42.

Péfaur, J.E, J.L. Yáñez, and F.M. Jaksic. 1979. Biological and environmental aspects of a mouse outbreak in the semiarid region of Chile. Mammalia 43:313-322.

Pérez, C., M. Fiebig-Wittmaack, J. Cepeda-Pizarro, and J. Pizarro-Araya. 2009. Desastres naturales y plagas en el valle del Río Elqui. Pages 315 353. In: J. Cepeda-Pizarro (ed.). Los Sistemas Naturales de la Cuenca del Río Elqui (Región de Coquimbo, Chile): Vulnerabilidad y Cambio del Clima. Ediciones Universidad de La Serena, La Serena, Chile.

Platnick, N.I. 1983. A review of the chilensis group of the spider genus Echemoides (Araneae, Gnaphosidae). American Museum Novitates 2760:1-56.

Platnick, N.I. 2008. The World Spider Catalog, Version 9.0 (on line) Available at: http:/www.research.amnh.org/entomology/spiders/catalog/ accessed November 2008.

Ramírez, M.J. 1999. Orden Araneae. Pages 39-59. In: F.A. Crespo, M.S. Iglesias, and A.C. Valverde (eds.). El ABC en la Determinación de artrópodos I. Ediciones CCC Educando, Buenos Aires, Argentina.

Retana, J.A. 2000. Relación entre algunos aspectos climatológicos y el desarrollo de la langosta centroamericana Schistocerca piceifrons piceifrons en el Pacífico Norte de Costa Rica durante la fase cálida del fenómeno El Niño-Oscilación Sur (ENOS). Tópicos Meteorológicos y Oceanográficos 7:73-87.

Ripa, R, and F. Rodríguez. 2000. Plagas de cítricos, sus enemigos naturales y manejo. Colección Libros Instituto de Investigaciones Agropecuarias, Santiago, Chile. $N^{\circ} 3.151$ pp.

Rojas, S. 2005. Control biológico de plagas en Chile. Historia y avances. Colección Libros Instituto de Investigaciones Agropecuarias, Santiago, Chile $\mathrm{N}^{\circ} 12.123 \mathrm{pp}$.

Roth, V.D. 1993. Spider genera of North America: with keys to families and genera, and a guide to literature. American Arachnological Society, Gainesville, Florida, USA. 203 pp.

Schenone, H. 2003. Cuadros tóxicos producidos por mordeduras de araña en Chile: latrodectismo y loxoscelismo. Revista Médica de Chile 131:437444.

Schneider, S.H. 1993. Scenarios of global-warming. Pages 234-250. In: P.M. Kareiva, J. Kingsolver, and R. Huey (eds.). Biotic interactions and global change. Sinauer Associates, Sunderland, Massachusetts, USA.

Schotterer, U., M. Grosjean, W. Stichler, P. Ginot, C. Kull, H. Bonnaveira, B. Francou, H.W. Gaggeler, R. Gallaire, G. Hoffmann, B. Pouyaud, E. Ramírez, M. Schwikowski, and J.D. Taupin. 2003. Glaciers and climate in the Andes between the Equator and 30 degrees $\mathrm{S}$ : What is recorded under extreme environmental conditions?. Climatic Change 59:157-175.

Skinner, K.M., and R.D. Child. 2000. Multivariate analysis of the factors influencing changes in Colorado grasshopper abundance. Journal of Orthoptera Research 9:103-109.

Thiéry, D., and J. Moreau. 2005. Relative performance of European grapevine moth (Lobesia botrana) on grapes and other hosts. Oecologia 143:548-557.

Vetter, R.S. 2008. Spiders of the genus Loxosceles (Araneae, Sicariidae): a review of biological, medical and psychological aspects regarding envenomations. Journal of Arachnology 36:150-163.

Vetter, R.S., and G.K. Isbister. 2008. Medical aspects of spider bites. Annual Review of Entomology 53:409-429.

Villagrán, C., and J.J. Armesto. 1993. Full and late glacial paleoenvironmental scenarios for the west coast of southern South America. Pages 195-207. In: H.A. Mooney, E.R. Fuentes, and B.I. Kronberg. (eds.). Earth System Response to Global Change. Academic Press, San Diego, USA.

Volney, W.J.A., and R.A. Fleming. 2000. Climate change and impacts of boreal forest insects. Agriculture Ecosystems and Environment 82:283294.

Zambrano, A., J. González, and G. Callejas. 2005. Desenlace fatal por loxoscelismo cutáneo visceral. Revista Médica de Chile 133:219-223.

Zapfe, H. 1961. La familia Filistatidae en Chile. Investigaciones Zoológicas Chilenas 7:145-150.

Zavala, H., and H. Trigos. 2009. Hidrología de la cuenca del río Elqui. Pages 85-182. In: J. Cepeda-Pizarro (ed.). Los Sistemas Naturales de la Cuenca del Río Elqui (Región de Coquimbo, Chile): Vulnerabilidad y Cambio del Clima. Ediciones Universidad de La Serena, La Serena, Chile. 
